\title{
ABR, a novel inducer of transcription factor C/EBPa, contributes to myeloid differentiation and is a favorable prognostic factor in acute myeloid leukemia
}

\author{
Carolina Yaeko Namasu ${ }^{1}$, Christiane Katzerke ${ }^{1}$, Daniela Bräuer-Hartmann ${ }^{1}$, \\ Alexander Arthur Wurm ${ }^{1}$, Dennis Gerloff ${ }^{2}$, Jens-Uwe Hartmann ${ }^{1}$, Sebastian \\ Schwind $^{1}$, Carsten Müller-Tidow ${ }^{3}$, Nadja Hilger ${ }^{4}$, Stephan Fricke $^{4}$, Maximilian \\ Christopeit ${ }^{5}$, Dietger Niederwieser ${ }^{1}$ and Gerhard Behre ${ }^{1}$ \\ ${ }^{1}$ Division of Hematology and Oncology, University Hospital Leipzig, Leipzig, Germany \\ ${ }^{2}$ Division of Dermatology and Venereology, University Hospital Halle, Halle, Germany \\ ${ }^{3}$ Division of Hematology and Oncology, University Hospital Heidelberg, Heidelberg, Germany \\ ${ }^{4}$ Fraunhofer Institute for Cell Therapy and Immunology, Leipzig, Germany \\ ${ }^{5}$ Department of Stem Cell Transplantation, University Medical Center Hamburg-Eppendorf, Hamburg, Germany \\ Correspondence to: Gerhard Behre, email: gerhard.behre@medizin.uni-leipzig.de
}

Keywords: acute myeloid leukemia, $A B R, C / E B P a$, myelopoiesis, prognostic

Received: April 04, $2017 \quad$ Accepted: September 22, $2017 \quad$ Published: October 26, 2017

Copyright: Namasu et al. This is an open-access article distributed under the terms of the Creative Commons Attribution License 3.0 (CC BY 3.0), which permits unrestricted use, distribution, and reproduction in any medium, provided the original author and source are credited.

\section{ABSTRACT}

Active $B C R$ related $(A B R)$ gene deactivates ras-related $C 3$ botulinum toxin substrate 1 (RAC1), which plays an essential role in regulating normal hematopoiesis and in leukemia. BCR gene, closely related to ABR, acts as a tumor suppressor in chronic myeloid leukemia and has overlapping functions with $A B R$. Evidence for a putative tumor suppressor role of $A B R$ has been shown in several solid tumors, in which deletion of $A B R$ is present. Our results show downregulation of $A B R$ in AML. A block of ABR prevents myeloid differentiation and leads to repression of the myeloid transcription factor $\mathrm{C} / \mathrm{EBPa}$, a major regulator of myeloid differentiation and functionally impaired in leukemia. Conversely, stable overexpression of ABR enhances myeloid differentiation. Inactivation of the known ABR target RAC1 by treatment with the RAC1 inhibitor NSC23766 resulted in an increased expression of C/EBPa in primary AML samples and in AML cell lines U937 and MV4;11. Finally, AML patients with high $A B R$ expression at diagnosis showed a significant longer overall survival and patients who respond to azacitidine therapy showed a significant higher ABR expression. This is the first report showing that $A B R$ expression plays a critical role in both myelopoiesis and AML. Our data indicate the tumor suppressor potential of $A B R$ and underline its potential role in leukemia therapeutic strategies.

\section{INTRODUCTION}

Acute myeloid leukemia (AML) in adults is still associated with poor outcome [1]. AML involves activation of oncogenes or deactivation of tumor suppressor genes, and a block of differentiation caused by reduced function of transcription factors [2,3]. Active $\mathrm{BCR}$ related (ABR) protein shares high homology with BCR (Breakpoint Cluster Region) [4], which acts as a tumor suppressor in chronic myeloid leukemia [5] and meningiomas [6]. Previous studies have reported a putative tumor suppressive role of $A B R$ in several solid tumors, such as medulloblastoma [7], astrocytomas [8], and breast cancer [9] in which deletion of $A B R$ has been found. Furthermore, ABR knockdown inhibited apoptosis and promoted colony formation from dissociated human embryonic stem cells [10]. $A B R$ gene is ubiquitously expressed in mouse tissues, including bone marrow 
[11]. In mouse cells of the innate immune system, such as neutrophils and macrophages, the lack of a functional ABR protein results in abnormal reactivity of the innate immune system $[11,12]$. ABR and the relative BCR specifically act as negative regulators of RAC1, which has been found to be active in myeloid-associated diseases [13-16] and plays crucial roles in many functions of the innate immune system [17]. Importantly, a previous study has found that RAC1 protein was overexpressed in AML patients [16]. Despite the known role of BCR in leukemia, there have been no reports showing any specific function of ABR in myeloid differentiation and AML.

The transcription factor $\mathrm{C} / \mathrm{EBP} \alpha$ is a major regulator of myeloid differentiation and functionally impaired in leukemia [18]. Furthermore, C/EBP $\alpha$ deficient hematopoietic cells do not effectively generate granulocyte-monocyte progenitors from the common myeloid progenitor $[19,20] . \mathrm{C} / \mathrm{EBP} \alpha$ is also able to activate promoters of receptors for the granulocyte- $(G-C S F)$ and monocyte-colony stimulating factor $(M-C S F)[21,22]$. Interestingly, a previous study reported that M-CSF induced ABR activity in mouse bone marrow macrophages [23]. However, until now there is no evidence of a functional involvement of $\mathrm{ABR}$ in $\mathrm{C} / \mathrm{EBP} \alpha$-dependent mechanisms in myelopoiesis. For this reason, we investigated the role of ABR in myelopoiesis and AML.

In this study, we examined the $A B R$ expression pattern during normal and malignant myelopoiesis. A high $A B R$ expression at diagnosis was associated with a significant longer overall survival of patients with de novo AML in complete remission which received hematopoietic stem cell transplantation. Furthermore, AML patients who responded to an azacitidine-based therapy showed a significant higher $A B R$ expression than patients which did not respond. We also investigated the function of $\mathrm{ABR}$ in connection to $\mathrm{C} / \mathrm{EBP} \alpha$. SiRNA-mediated block of ABR expression represses $\mathrm{C} / \mathrm{EBP} \alpha$ protein expression and prevents myeloid differentiation. In addition, we demonstrate that $A B R$ induces the expression of $\mathrm{C} / \mathrm{EBP} \alpha$ as well as $M-C S F R, G-C S F R$ and $m i R-223$, which has been shown by our group and others as direct target of $\mathrm{C} / \mathrm{EBP} \alpha$ in granulopoiesis [21, 22, 24-26]. Finally, the inactivation of the known ABR target RAC1 by treatment with the RAC1 inhibitor NSC23766 resulted in an increased expression of $\mathrm{C} / \mathrm{EBP} \alpha$. Altogether, our data present the first evidence that $\mathrm{ABR}$ acts as new enhancer of $\mathrm{C} / \mathrm{EBP} \alpha$ mRNA and protein levels and as favourable prognostic factor in AML.

\section{RESULTS}

\section{ABR mRNA expression is repressed in acute myeloid leukemia (AML) and high ABR expression associates with improved outcome}

A previous study showed that BCR acts as a tumor suppressor in chronic myeloid leukemia [5] and meningiomas [6]. Additionally, evidence for a putative anti-oncogenic role of ABR has been shown in several solid tumors [9-11] and in t(8;21) AML [31]. By qPCR we ascertained the $A B R$ expression pattern in bone marrow samples of 63 primary AML patients at diagnosis and 3 healthy control bone marrow samples (Supplementary Table 4). Our data showed that $A B R$ expression is strikingly repressed in bone marrow of AML patients independent of the subtype (Figure 1A). A recent treatment approach for AML is the allogeneic hematopoietic stem cell transplantation after nonmyeloablative conditioning (NMA-HSCT). Which uses a low dose of total body irradiation to enable older patients to undergo HSCT [27]. By using the median cut algorithm in a subset of 36 de novo AML patients who received NMA-HSCT transplantation in complete remission, we observed that patients with high $A B R$ expression showed a significant longer overall survival than patients with low $A B R$ expression (Figure 1B). We observed that high $A B R$ expression in AML correlates with favorable clinical and molecular patient characteristics in AML, such as a significant lower percentage of blasts in peripheral blood $(P=$ .006) and high expression of miR-181a $(P<.001)$ as well as tendencies for a lower number of white blood cells (WBC) $(P=.06)$, and lower number of blasts in bone marrow $(P=.06)$ (Table 1$)$. We did not observe a significant difference in the mutational status of the prognostic relevant myeloid genes CEBPA and FLT3 between high and low ABR expressers (Supplementary Table 3). However, a low ABR expression was associated with mutated NPM1 $(P=.04)$.

\section{ABR is increased during myelopoiesis}

We could show that ABR expression is suppressed in AML in general. Furthermore, it is known that ABR protein shares M-CSF-induced activity with the related $\mathrm{BCR}$ protein in mouse bone marrow macrophages [23]. A previous study could show that $\mathrm{C} / \mathrm{EBP} \alpha$ has the capacity to direct monocytic development from myeloid progenitors [20]. In addition, $\mathrm{C} / \mathrm{EBP} \alpha$ is able to activate the M-CSFreceptor (M-CSF-R) promoter [21]. To access the role of ABR in myelopoiesis, we analysed ABR expression during myeloid differentiation of mouse bone marrow cells. The cells were cultured in the presence of M-CSF $(20 \mathrm{ng} / \mathrm{ml})$ or G-CSF (1 ng/ml) for seven days. Total RNA was isolated and quantified using qPCR. We could demonstrate that $A B R$ expression was significantly increased upon M-CSF or G-CSF-stimulated differentiation of mouse bone marrow cells (Figure 2A-2B). The differentiation status of the cells was evaluated by qPCR based measurement of the monocytic marker M-CSFR and the granulocytic marker G-CSFR. The mouse bone marrow cells showed an induction of G-CSFR (up to 14 fold) and M-CSFR (up to 19 fold), respectively (Figure 2C-2D). Additionally, 
Table 1: Comparison of clinical and molecular characteristics of AML patients who received NMAHSC transplantation with high versus low ABR expression

\begin{tabular}{lccc}
\hline \multicolumn{1}{c}{ Characteristic } & Low ABR $(\boldsymbol{n}=\mathbf{3 1})$ & High ABR $(\boldsymbol{n}=\mathbf{3 2})$ & $\boldsymbol{P}$ value \\
\hline Median WBC count, 10\%/L (range) & $8.1(1-385)$ & $4.6(0.7-140)$ & 0.06 \\
Median PB blasts, \% (range) & $50(2-97)$ & $21(0-97)$ & 0.006 \\
Median BM blasts, \% (range) & $80(27-95)$ & $60(10-94)$ & 0.06 \\
NPM1 mutation & $11(37 \%)$ & $4(13 \%)$ & 0.04 \\
High miR-181 a-1 expression, $n(\%)$ & $9(29 \%)$ & $23(71 \%)$ & $<0.001$ \\
High miR-181 a-2 expression, $n(\%)$ & $8(26 \%)$ & $24(75 \%)$ & $<0.001$ \\
\hline
\end{tabular}

Abbreviations: WBC, white blood count; PB, peripheral blood; BM, bone marrow. The median expression value was used as a cut point. It was calculated based on the expression levels assessed by qPCR. $P$-values compare patients who have low ABR expression versus high ABR expression by log rank test.

myeloid differentiation was assessed by flow cytometry using the myeloid surface marker CD11b and the mouse monocytic marker F4/80 and granulocytic marker Gr-1 (Figure 2E-2F).

\section{ABR contributes to myeloid differentiation}

A previous study has shown that $A B R$ is active upon MCSF stimulation in mouse bone marrow macrophages [23]. To further understand how the ABR activity is biologically significant in the context of myelopoiesis, we carried out differentiation experiments in U937 cells. U937 cells differentiate to macrophages during PMA (phorbol 12-myristate 13-acetate) induction [32]. The differentiation was confirmed by CD11b measurement (Figure 3A). By qPCR, we observed that $\mathrm{ABR}$ and M-CSF-R expression levels are increased significantly during differentiation (Figure 3B-3C). To further analyze the role of ABR in differentiation, we transfected U937 cells with ABR siRNA or control siRNA. Six hours after transfection, the cells were stimulated with 1nM PMA. We found that a block of ABR expression resulted in a $53 \%$ diminution of $C E B P A$ expression levels after PMA treatment (Figure 3D). The flow cytometry analysis revealed that ABR knockdown in leukemic U937 cells leads to a significant reduction of the surface marker CD11b in comparison to the control siRNA transfected cells after PMA treatment (Figure $3 \mathrm{E})$. ABR knockdown was verified by western blot and showed a $40 \%$ reduction of the ABR protein 24 hours after siRNA treatment in comparison to the control. Analysis of $\mathrm{CEBP} \alpha$ protein revealed a $30 \%$ reduction of $\mathrm{C} / \mathrm{EBP} \alpha$ protein levels 24 hours after siRNA mediated knock down of ABR (Figure 3F). Conversely, lentiviral overexpression of ABR in U937 cells followed by treatment with PMA for $48 \mathrm{~h}$ showed a 2.3-fold increase in the CD11b positive cell population (Figure $3 \mathrm{G}$ ). These findings illustrate a specific role of ABR in PMA induced monocytic differentiation.

\section{$A B R$ induces $C / E B P \alpha$ expression and thereby increases the expression of M-CSF-R, G-CSF-R and miR-223}

Because ABR knockdown reduced $\mathrm{C} / \mathrm{EBP} \alpha$ on mRNA and protein level, we next examined the ability of $\mathrm{ABR}$ to regulate the expression of $\mathrm{C} / \mathrm{EBP} \alpha$. Thus, we performed transient overexpression of $\mathrm{ABR}$ and measured resulting $\mathrm{C} / \mathrm{EBP} \alpha$ protein levels. Here, we could demonstrate that enforced $\mathrm{ABR}$ expression for 24 hours leads to a 2.6-fold increase in $\mathrm{C} / \mathrm{EBP} \alpha$ mRNA and a 2.4-fold enhancement of $\mathrm{C} / \mathrm{EBP} \alpha$ protein in $\mathrm{U} 937$ cells (Figure 4A-4B). Conversely, the co-transfection of $\mathrm{C} / \mathrm{EBP} \alpha$ siRNA and ABR for 24 hours blocked ABRmediated induction of $C E B P A$ and its targets $G-C S F-R$, $M-C S F-R$ and miR-223 as well (Figure 4C-4F). Interestingly, the inactivation of the known ABR target RAC1 by treatment with the RAC1 inhibitor NSC23766 resulted in a significant increase of CEBPA mRNA to $87 \%$ (Figure $4 \mathrm{G}$ ). These data indicate a role of $\mathrm{ABR}$ in the $\mathrm{C} /$ $\mathrm{EBP} \alpha$ regulation.

\section{Rac1 inhibitor induced C/EBP $\alpha$ expression in primary AML cells}

Because Rac1 inhibition increased $C / E B P \alpha$ expression, we investigated the effect of Rac inactivation in primary AML cells. To address this issue, we treated primary AML samples with the Rac1 inhibitor NSC23766. We could show that Rac1 inhibitor treatment induced the expression of $\mathrm{C} / \mathrm{EBP} \alpha$ up to 7 fold (Figure 5A) and enhanced the percentage of apoptotic cells up to $60 \%$ (Figure 5C). We also observed that leukemic MV4;11 cells exhibited a 7-fold increase in the expression of $\mathrm{C} / \mathrm{EBP} \alpha$ (Figure 5B). Furthermore, in MV4;11 cells NSC23766treatment caused a 6-fold increase in apoptosis (Figure 5D). In addition, we analysed ABR expression in the primary AML samples. We found that AML sample \#2 had a reduced $A B R$ expression in comparison to $A M L$ 
A

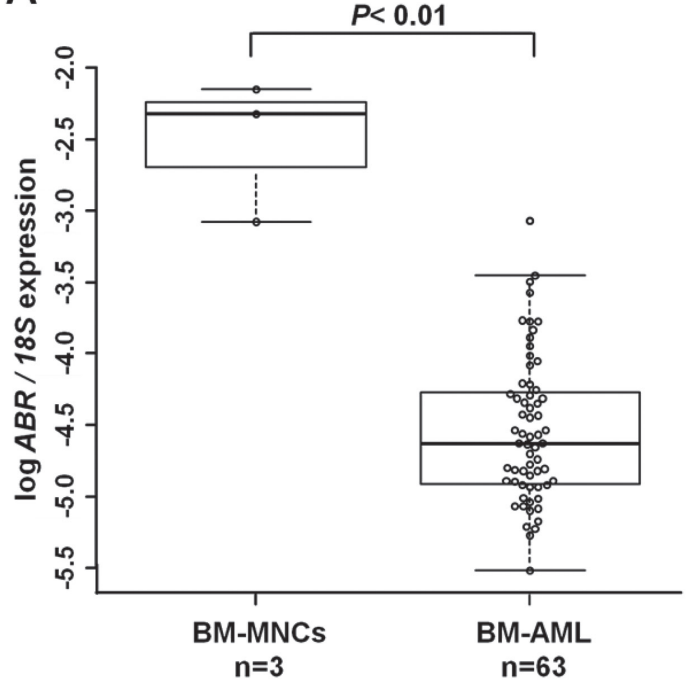

B

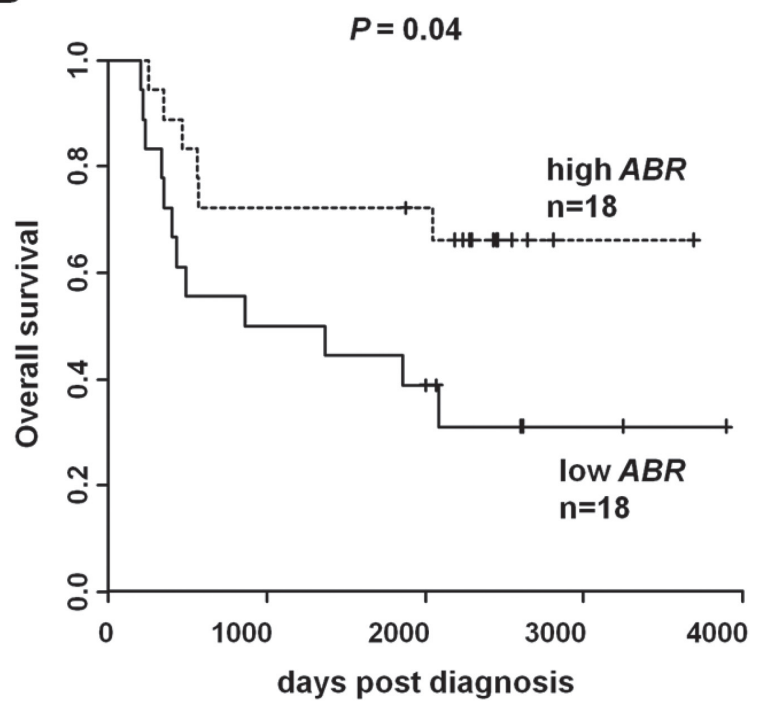

Figure 1: ABR expression is downregulated in acute myeloid leukemia (AML) and high ABR expression is associated with improved outcome. (A) qPCR for ABR was carried out using bone marrow cells derived from AML patients at diagnosis $(n=63)$. Values were normalized to $18 \mathrm{~S}$ and further to the expression level of bone marrow mononuclear cells (BM-MNCs) from healthy donors $(n=3)$. (B) Overall survival of the de novo AML patients in complete remission who received HSC transplantation $(n=36)$ is presented in Kaplan-Meier plots. ABR expression levels are cut at median. Log rank test was used for statistical evaluation.
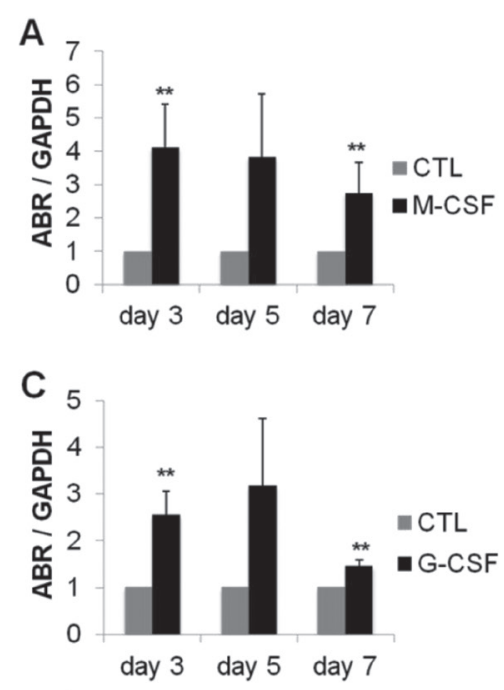

$E$

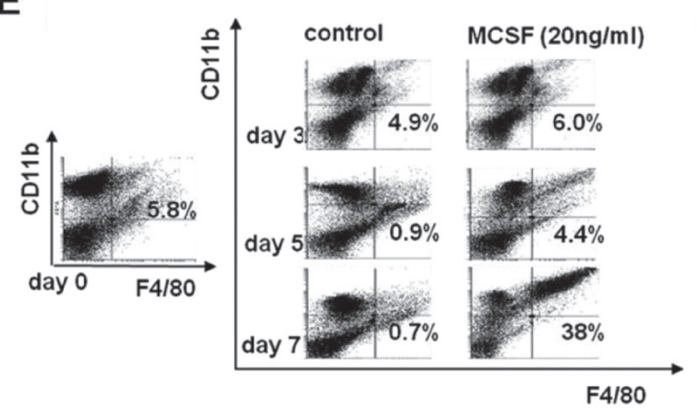

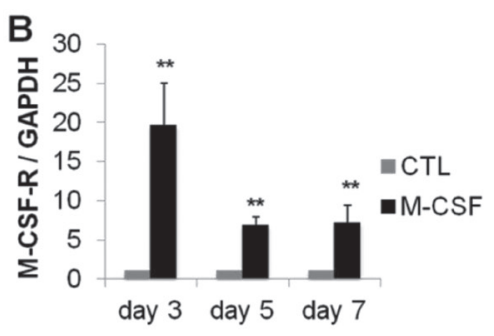

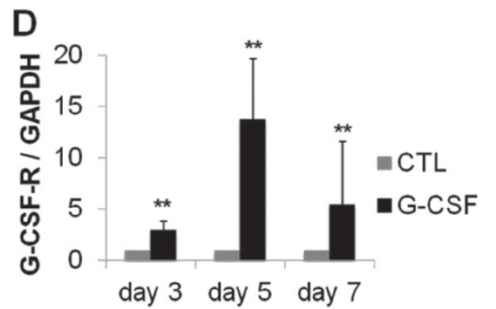

$\mathbf{F}$

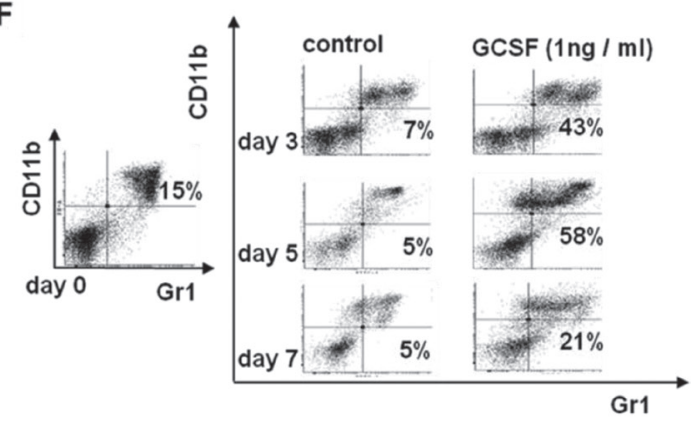

Figure 2: ABR expression is increased during myelopoiesis of mouse bone marrow cells. Bone marrow cells derived from wild-type C57B1/6 mice were treated with M-CSF or G-CSF for 7 days. (A-D) qPCR was carried out with oligonucleotides for ABR, M-CSF-R and G-CSF-R, respectively. Values were normalized to GAPDH and to the expression level of control treated cells (CTL). (E-F) FACS analysis was performed using CD11b and mouse specific macrophage (F4/80) and granulocyte (Gr1) antibodies. Total data are represented as mean $\pm \mathrm{SD}$ from 3 representative experiments. ${ }^{* *} P \leq .01 ;{ }^{*} P \leq .05$. 
A

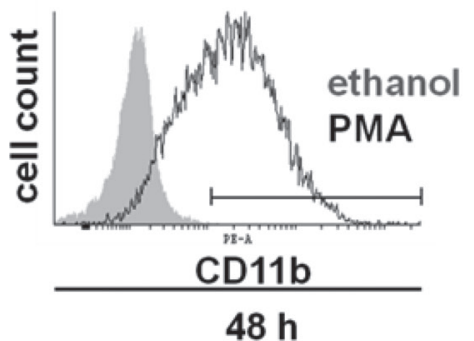

C

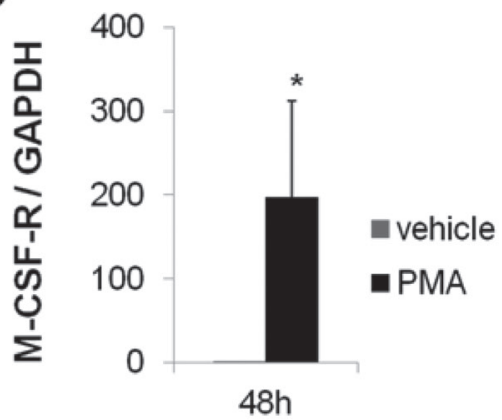

E

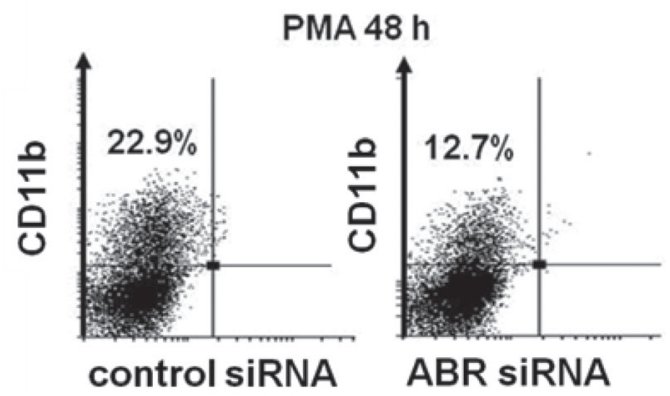

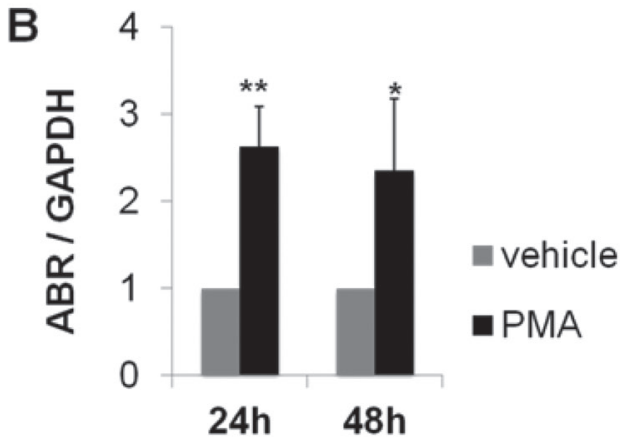

D

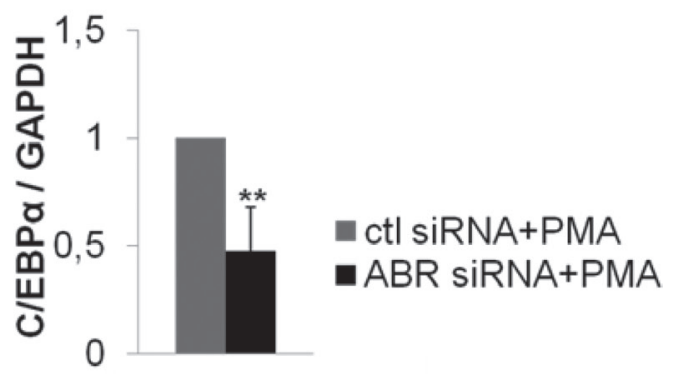

$\mathbf{F}$

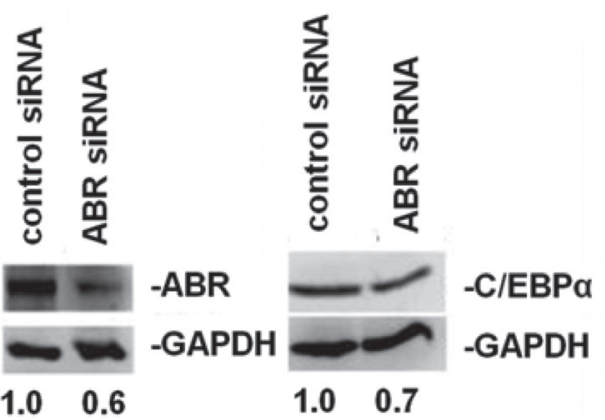

G

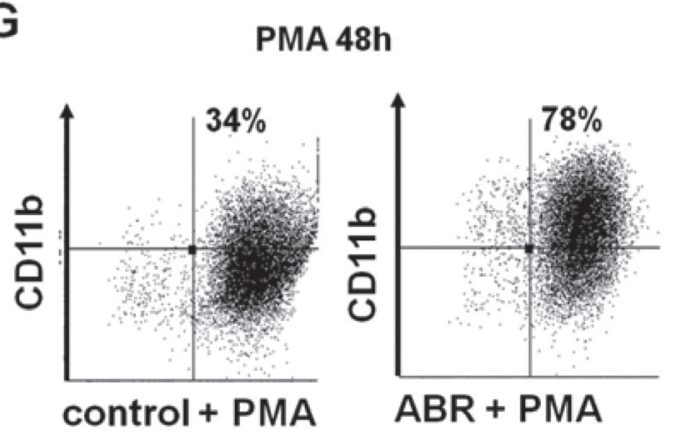

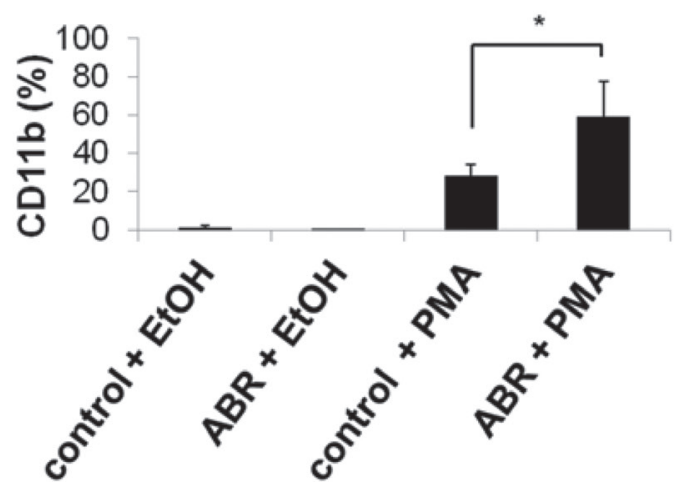

Figure 3: ABR promotes myeloid differentiation. (A-C) U937 cells were treated with PMA (10nM) for the determined time points. (A) FACS analysis was performed using CD11b antibody. (B-C) Total RNA was analysed by qPCR with oligonucleotides for ABR (B) and M-CSF-R (C). Values were normalized to GAPDH and further to the expression level of control treated cells (vehicle). (D-E) U937 cells were transfected with ABR siRNA or control siRNA. Six hours after transfection, cells were stimulated with PMA (1nM) for 48 hours. (D) qPCR was carried out with oligonucleotides for C/EBP $\alpha$. Values were normalized to GAPDH and to the expression level of control treated cells (ctl). (E) FACS analysis was performed using CD11b antibody. (F) U937 cells transfected with ABR siRNA or control siRNA. Total protein was analysed by western blot using ABR and $\mathrm{C} / \mathrm{EBP} \alpha$ antibodies. Values below the gel image indicate the protein levels normalized to GAPDH. (G) U937 cells were stably transfected with lentiviral vector EYFP-ABR in pCCL-cppt-MNDU3 and treated with PMA (10nM) for 48h. FACS analysis was performed using CD11b antibody. Total data are represented as mean \pm SD from 3 independent experiments. ${ }^{* *} P \leq .01 ;{ }^{*} P \leq .05$. 
sample \#1. Interestingly, we observed that the effects of Rac inhibition with NSC23766 are enhanced in AML sample \#2, which showed a $60 \%$ increase in the apoptotic cell number in comparison to AML sample \#1, which had only 30\% increase (Figure 5E).

\section{High ABR expression associates with response to azacitidine treatment in AML patients}

Azacitidine is an inhibitor of DNA methylation that induces tumor suppressor gene expression [33]. As we hypothesize that $A B R$ could act as a tumor suppressor gene in AML, we examined the $A B R$ expression in azacitidinetreated AML patients (Supplementary Table 4). To this end, bone marrow samples from 21 AML patients $(>60$ years) were collected at diagnosis and $A B R$ expression was quantified by qPCR method (Figure 6A). Our data showed that $A B R$ expression is repressed in bone marrow of AML patients at diagnosis in comparison to healthy control samples (Figure 6A). After azacitidine therapy, patients were divided into two groups (responders and nonresponders). Response was defined as a blast clearance $(\leq 5 \%)$ in the bone marrow on day 15 after start of the first azacitidine treatment cycle [28] which could be achieved in 11 of 21 patients (42\%) (Figure 6C). We found that a high $A B R$ expression significantly correlated with a better response after azacitidine treatment (Figure 6B). These observations suggest that $A B R$ as a relevant target for the treatment of leukemia.

\section{ABR increases azacitidine-induced apoptosis}

Because our data show that ABR induces the transcription factor $\mathrm{C} / \mathrm{EBP} \alpha$ and is a favorable prognostic factor in AML, we were interested in the impact of ABR on AML treatment. Azacitidine is one of the most effective DNA demethylating agents used in cancer treatment and widely used for the treatment of acute myeloid leukemia [34]. We could show that azacitidine is able to induce apoptosis in U937 cells (Figure 7A) and azacitidine alone leads to induction of the mRNA expression levels of $A B R$ and $C E B P A$ in U937 cells (Figure 7B-7C). To investigate the effect of ectopic ABR expression in azacitidine therapy, we stably overexpressed $A B R$ in U937 cells and treated the cells with $15 \mu \mathrm{M}$ azacitidine. ABR significantly enhanced the proapoptotic effect of azacitidine (2.7 fold with $15 \mu \mathrm{M}$ azacitidine for 48 hours) in comparison to the control (Figure 7A). These results suggest that a putative epigenetic modification may be responsible for a reduced expression of $A B R$ in AML.

\section{DISCUSSION}

ABR deactivates the small GTPase Rac1, a master molecular switch that regulates several cellular processes, including maintenance and expansion of leukemic cells
[16] and regulation of immune cell functions [17]. Previous studies of ABR have mainly focused on ABR involvement in immune regulation. Mice lacking ABR exhibit an increased susceptibility to several inflammatory diseases, demonstrating that $\mathrm{ABR}$ activity is required for appropriate control of innate immune response in vivo [12, 35, 36]. Furthermore, a connection between ABR deletion and several non-hematopoietic tumors has been reported [7-9]. These observations suggest that ABR is a relevant target for the treatment of leukemia and possibly of several other types of cancer. An important recent finding is that active RAC1 promotes expansion of leukemic stem cells by mediating their interaction with stromal cells in mouse AML-ETO-9a model [16, 37]. This finding is supported by other studies, which reported that RAC1 is required for the engraftment phase of hematopoietic reconstitution in mice $[38,39]$. Similarly, MLL-AF9-transduced murine leukemic stem cells showed enhanced levels of active RAC [40]. Although the relative $\mathrm{BCR}$ is demonstrated to act as a tumor suppressor in leukemia [5], a specific function of ABR in myelopoiesis and leukemia has not been addressed. Therefore, in the present study, we utilize mouse bone marrow cells, leukemic cells and AML patient samples as models to investigate the role of ABR in myelopoiesis and leukemia. A previous report described a reduction of ABR expression in $\mathrm{t}(8 ; 21)$ AML [31]. Indeed, our analyses show that $A B R$ expression is strikingly reduced in AML among different subtypes (Figures 1A and 6A). Consistently, elevated levels of active RAC1, which is downregulated by ABR, have been previously described in primary human CD34 positive hematopoietic stem cells isolated from patients with AML [16]. Our study identifies a novel function of $\mathrm{ABR}$, showing that $\mathrm{ABR}$ contributes to myeloid differentiation (Figure 3). By analyzing a subset from de novo AML patients, in complete remission which received HSC transplantation, we clearly see a prognostic correlation between a high $A B R$ expression and a longer survival of the patients (Figure 1B). In line with this, we could demonstrate that AML patients with higher $A B R$ expression levels respond better to clinical azacitidine-based therapy (Figure 6B). In accordance with this, we observed that high $A B R$ expression at diagnosis is associated with favorable clinical and molecular patient characteristics, (Table 1), which have been shown to be correlated with favorable outcome in AML patients [41, 42]. A low $A B R$ expression was associated with mutated NPM1. NPM1 mutation in the absence of fmslike tyrosine kinase 3 internal tandem duplications (FLT3$I T D)$ is associated with a relatively favorable prognosis. However, NPM1 is a late driver mutation [43], identified as being frequently overlapped with FLT3-ITD, which is associated with an unfavorable prognosis [44]. Moreover, the persistence of NPM1 mutation was associated with a significantly higher risk of relapse [45]. Those data suggest that $A B R$ is a key mediator of tumor suppressor function in 
A

C
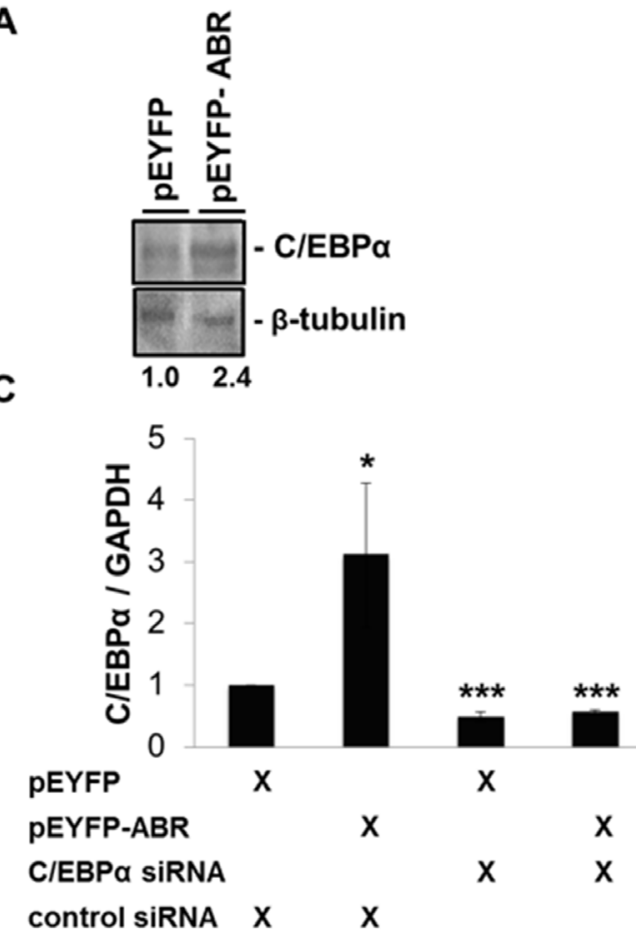

E

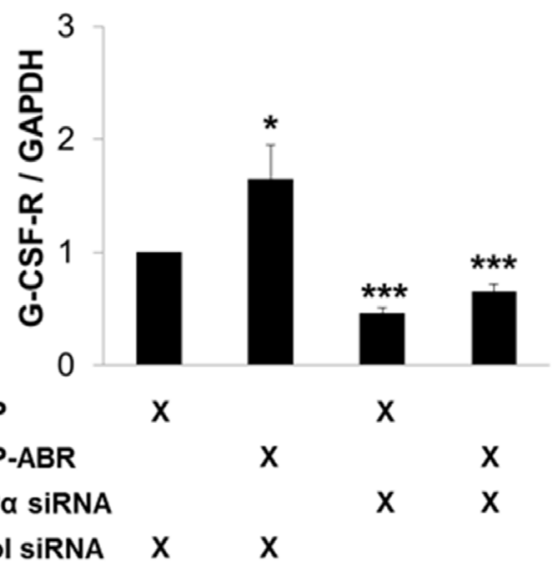

B

D
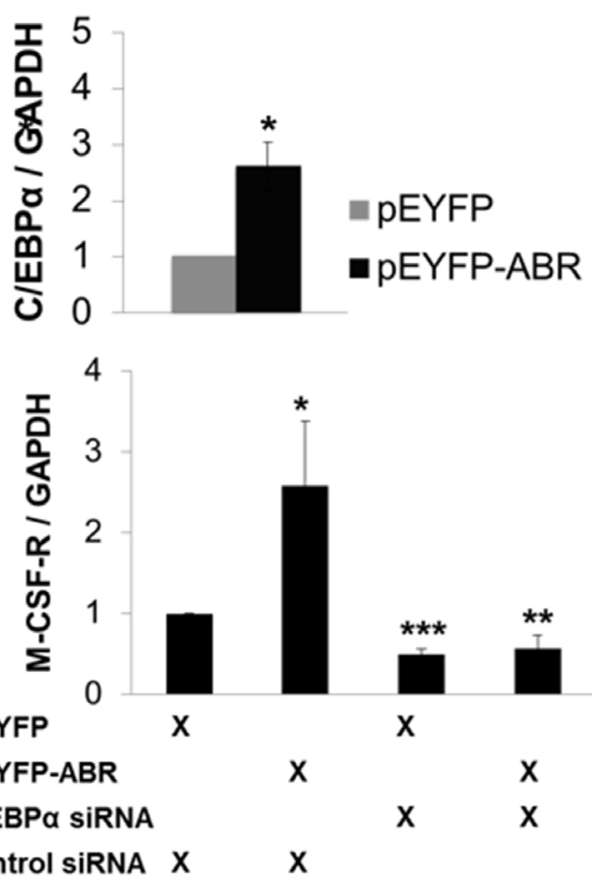

$\mathbf{F}$

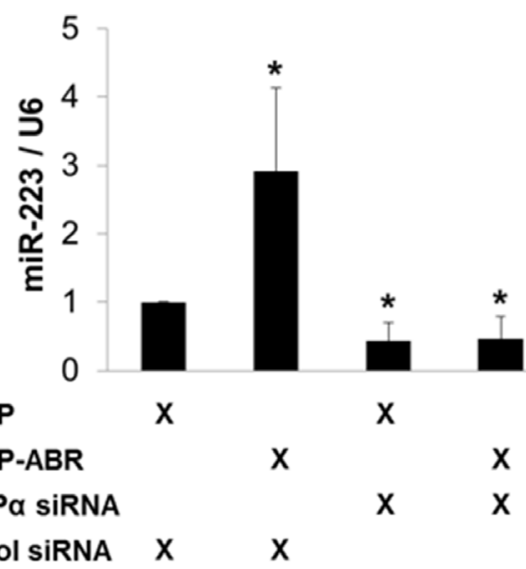

G

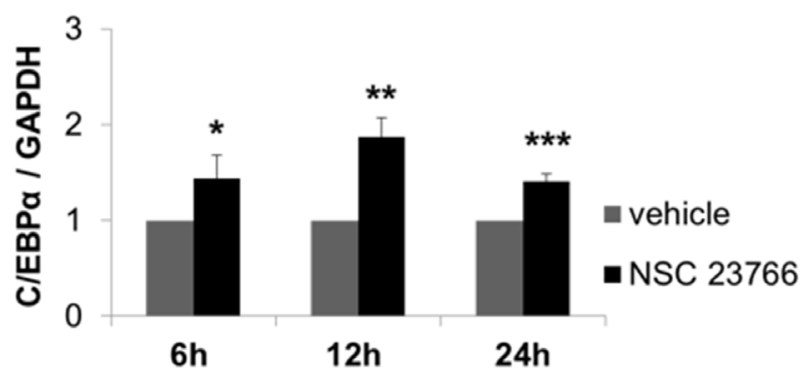

Figure 4: ABR induces C/EBP $\alpha$ expression and thereby increases the expression of M-CSF-R, G-CSF-R and miR-223. (A-B) U937 cells were transfected with ABR or empty vector for 24 hours. (A) Total protein was analysed by western blot with C/EBP $\alpha$ antibody. Values below the gel image indicate C/EBP $\alpha$ protein levels normalized to $\beta$-tubulin. (B) Total RNA was analysed by qPCR with oligonucleotides for C/EBP $\alpha$. Values were normalized to GAPDH. (C-F) U937 cells were co-transfected with ABR or empty vector along with $\mathrm{C} / \mathrm{EBP} \alpha$ siRNA or control siRNA for 24 hours. Total RNA was analysed by qPCR with oligonucleotides for C/EBP $\alpha$, M-CSF-R, G-CSF-R and miR-223. Values were normalized to GAPDH and to the expression level of control transfected cells. (G) U937 cell were treated with $100 \mu \mathrm{M}$ Rac1 inhibitor NSC23766 for the indicated time points. Total RNA was analysed by qPCR with oligonucleotides for $\mathrm{C} / \mathrm{EBP} \alpha$. Values were normalized to GAPDH and to the expression level of control treated cells $\left(\mathrm{H}_{2} \mathrm{O}\right)$. Total data are represented as mean \pm SD from 3 independent experiments. ${ }^{* * *} P \leq .001 ;{ }^{* *} P \leq .01 ;{ }^{*} P \leq .05$. 
AML. Conversely, a reduced ABR expression correlated with a disturbance of myeloid differentiation (Figure 3D) and worse outcome in AML (Figures 1B and 6B). This study provides the first evidence that repression of $A B R$ is a common phenomenon in AML with different subtypes (Figures 1A and 6A). Because RAC1 is downregulated by ABR [23], a reduction of $A B R$ expression might contribute to the accumulation of RAC1 in AML. In fact, Rac1 is active, overexpressed in chronic and acute

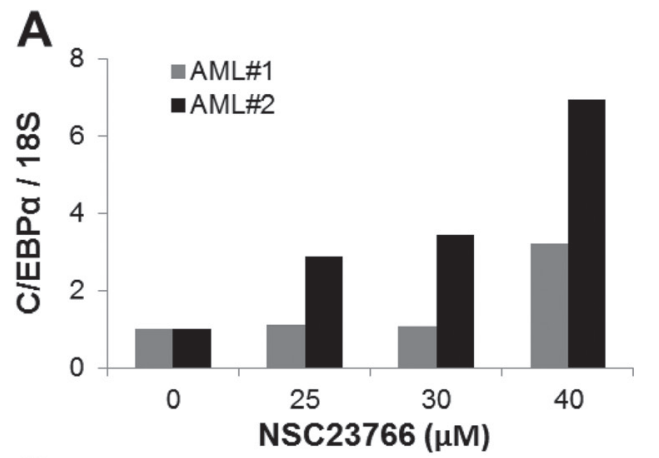

C
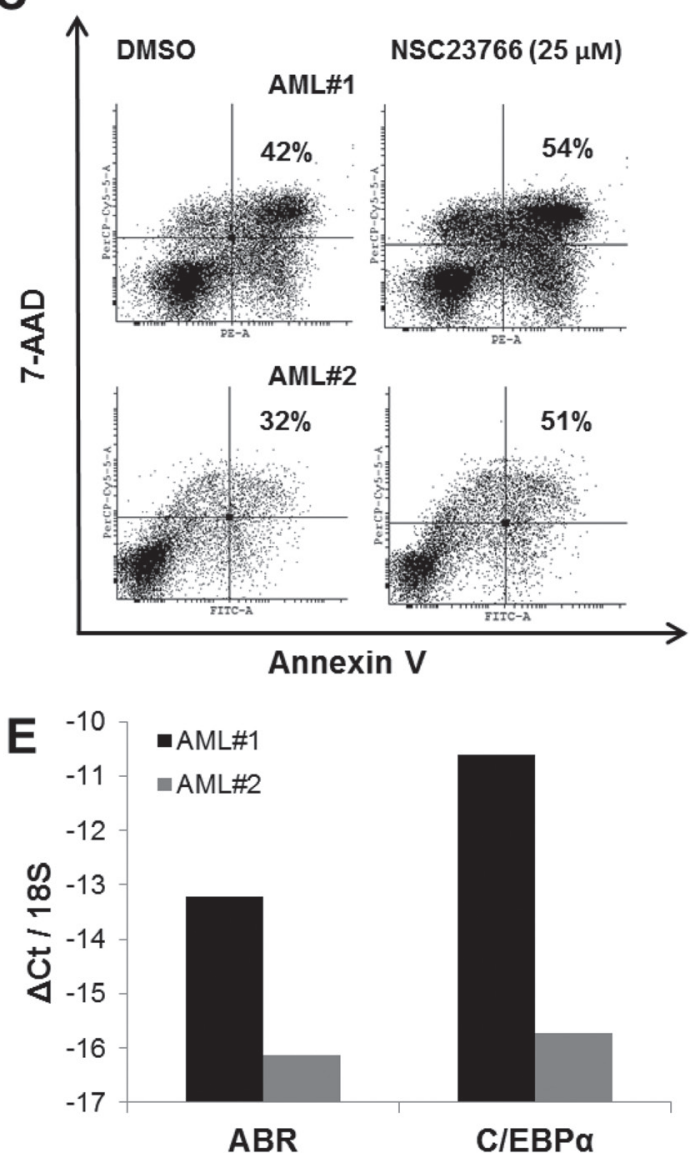

myeloid leukemia patients [14-16] and promotes leukemia development through enhancing leukemia cells' homing and retention in niche [37]. Interestingly, we found that Rac1 inhibition with NSC23766 induced $\mathrm{C} / \mathrm{EBP} \alpha$ expression in primary AML cells and in AML cell lines U937 and MV4;11 (Figures 4G and 5A-5B). Rac1 is involved in regulating the phosphorylation of the signal transducer and activator of transcription 3 (STAT3) [46], a transcription factor activated by tyrosine kinases

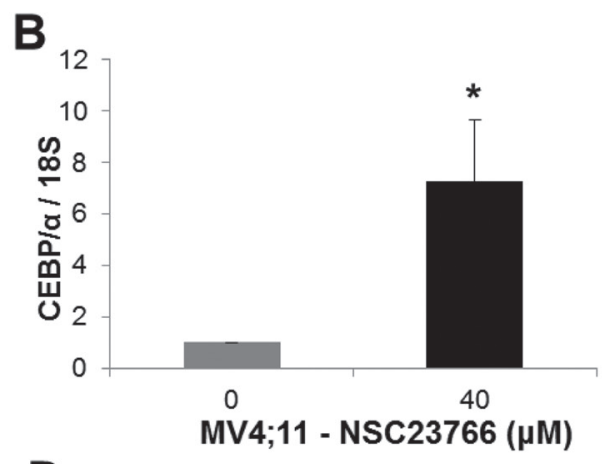

D
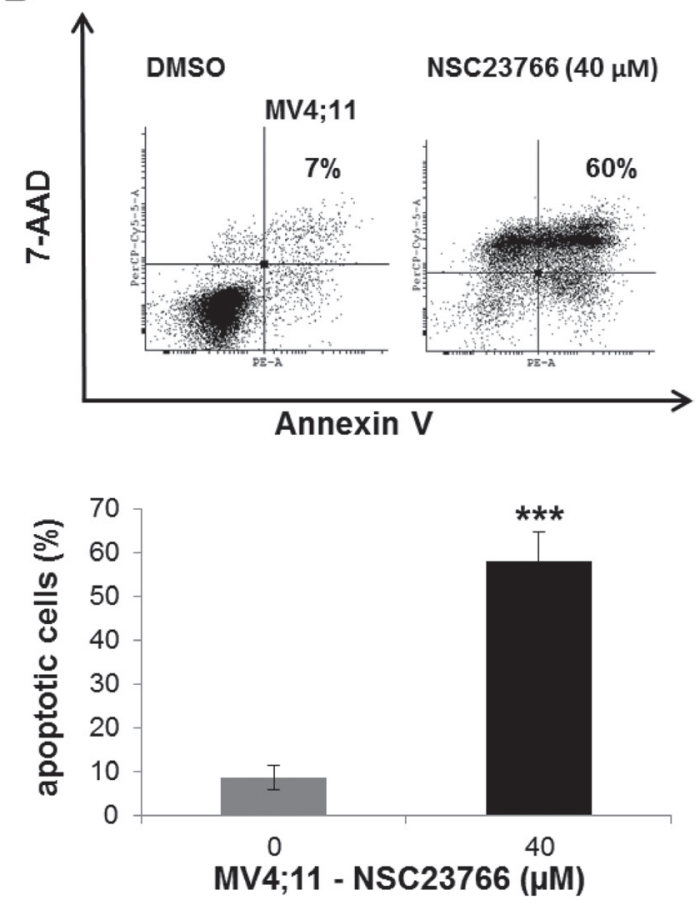

Figure 5: Rac1 inhibitor induced C/EBP $\alpha$ expression in AML primary cells. (A-B) AML primary cells (A) or AML MV4;11 cells (B) were treated with Rac1 inhibitor NSC23766 using the indicated concentrations for $72 \mathrm{~h}$ (A) or 48h (B). (A-B; E) Total RNA was analysed by qPCR with oligonucleotides for $\mathrm{C} / \mathrm{EBP} \alpha$. Values were normalized to $18 \mathrm{~S}$ and to the expression level of control treated cells (DMSO). (C-D) Flow cytometry analysis for Annexin V and 7-AAD staining in AML primary cells (C) or MV4;11 cells (D) treated with NSC23766. (E) Total RNA was analysed by qPCR with oligonucleotides for ABR and C/EBP $\alpha$. Values were normalized to $18 \mathrm{~S}$. Total data $(\mathrm{B}, \mathrm{D}-\mathrm{E})$ are represented as mean $\pm \mathrm{SD}$ from 3 independent experiments. ${ }^{* * *} P \leq .001 ;{ }^{* *} P \leq .01 ;{ }^{*} P \leq .05$. 
[47]. In acute myeloid leukemia, constitutive activation of STAT pathway has been reported in various studies [46, 48, 49]. In addition, phosphorylation of STAT3 results in the induction of c-myc proto-oncogene product (Myc) [46]. Several studies have shown that transcription factor $\mathrm{Myc}$ is able to negatively regulate $\mathrm{C} / \mathrm{EBP} \alpha$ expression and block $\mathrm{C} / \mathrm{EBP} \alpha$ transactivation function [50-52]. Consistently with those findings, Rac1 inhibition with siRNA or Rac1 inhibitor NSC23766 has been shown to repress Myc transcription [53]. Therefore it is tempting to speculate that ABR-mediated Rac inhibition might induce CEBPA gene transcription via Myc downregulation.

Azacitidine acts as a hypomethylating agent in myeloid malignancies [54] and is licensed for AML therapy [55]. We found that response to azacitidine treatment is associated with high $A B R$ expression in elderly patients with AML (Figure 6). We could show that ABR enhances azacitidine-induced apoptosis (Figure 7A). These data highlight the role of ABR in therapy response. Additionally, azacitidine treatment increased the expression levels of $A B R$ and $\mathrm{CEBP} \alpha$ (Figure 7C-7D), suggesting that a potential epigenetic modification may be responsible for downregulation of ABR in AML. Further, it is shown that the inactivation of the known ABR target Rac1 in leukemia increases chemotherapy-induced apoptosis $[37,56]$, supporting a possible mechanism of ABR action in AML therapy via inhibition of Rac1. In line with this, the treatment of leukemic cells with the Rac1 inhibitor NSC23766 resulted in an increased expression of $C E B P A$ (Figures 4G, 5A, 5B), suggesting that ABR might induce $C E B P A$ expression via Rac1 repression.

$\mathrm{C} / \mathrm{EBP} \alpha$ functions as a key mediator of myelopoiesis, which is a key step disrupted in distinct subtypes of AML [57]. The receptors for G-CSF (G-CSF-R) and M-CSF (M-CSF-R) as well the miR223 are direct targets of $\mathrm{C} / \mathrm{EBP} \alpha[21,22,25]$. A previous study from our group has shown that $\mathrm{C} / \mathrm{EBP} \alpha$ acts as a tumor suppressor gene by upregulating miR-223 in normal granulopoiesis [26]. In the present study, we show that $\mathrm{ABR}$ induces the transcription factor $\mathrm{C} / \mathrm{EBP} \alpha$ and thereby increases the expression of $G-C S F-R, M-C S F-R$ and miR223 (Figure 4A-4F) suggesting that ABR expression could have a significant role in myeloid differentiation and in leukemia through induction of the CEBPA gene and its target genes.

Taken together, we discovered ABR as a new critical player in myeloid differentiation. We show that myeloid differentiation inducers lead to increased expression levels of the ABR and CEBP $\alpha$ targets M-CSF-R and $\mathrm{G}-\mathrm{CSF}-\mathrm{R}$ in human and mouse myelopoiesis. A reduction of ABR expression leads to decreased $\mathrm{CEBP} \alpha$ levels and a minimized myeloid differentiation (Figure 8A). In AML, we observed a decreased ABR expression. Conversely, high ABR expression enhanced myeloid
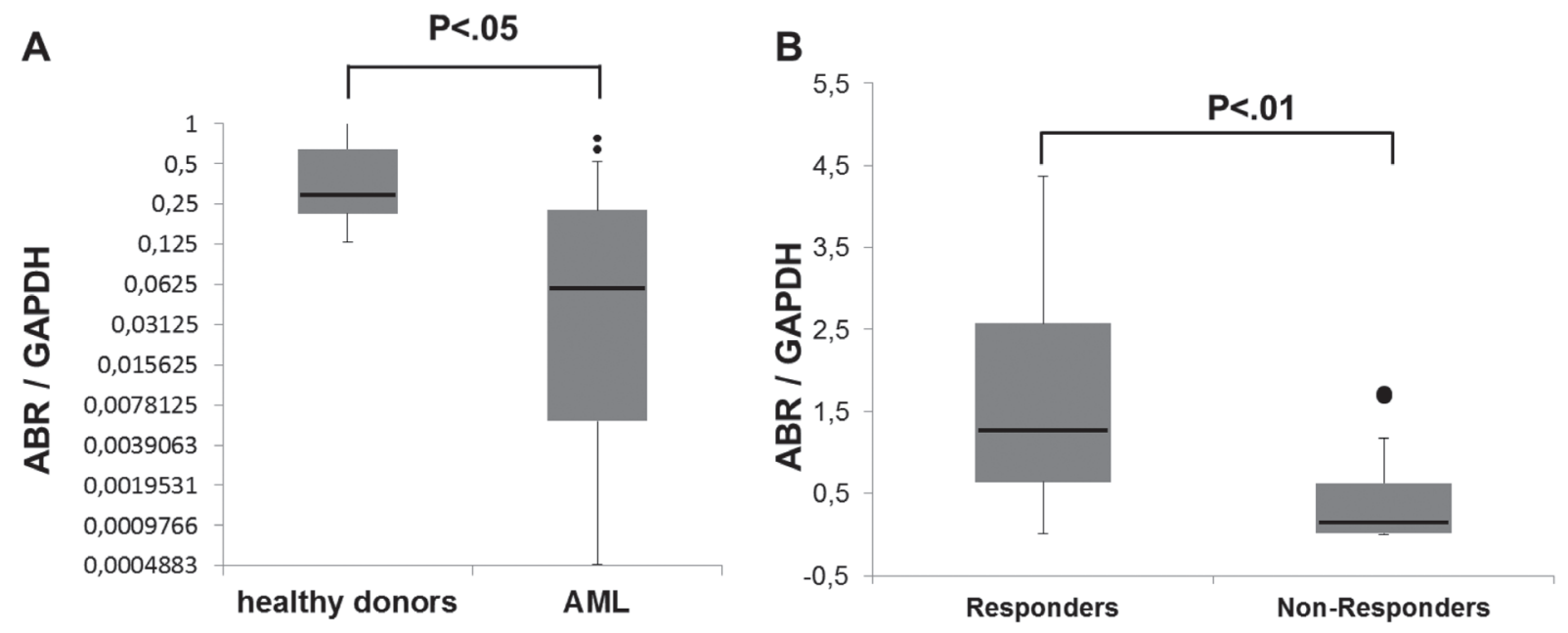

\begin{tabular}{lll}
\hline Characteristic & $\begin{array}{l}\text { Non-responders } \\
(\mathbf{n = 1 5 )}\end{array}$ & $\begin{array}{l}\text { Responders } \\
(\mathbf{n = 6})\end{array}$ \\
\hline Median age, y (range) & $68(62-79)$ & $72(64-78)$ \\
Gender, n (male / female) & $9 / 6$ & $4 / 2$ \\
Day 0 blasts, median (range) & $70(24-90)$ & $57(20-95)$ \\
Day 15 blasts, median (range) & $63,5(10-90)$ & $\leq 5$ \\
\hline
\end{tabular}

Figure 6: Response to azacitidine treatment in AML patients associates with high ABR expression. (A-B) qPCR for $A B R$ was carried out using bone marrow cells derived from AML patients at diagnosis $(n=21)$. Values were normalized to GAPDH and to the expression level of bone marrow mononuclear cells (BM-MNCs) from healthy donors $(n=3)$. Kruskal test was used for statistical evaluation. (C) Characteristics of azacitidine-treated AML patient samples used for $A B R$ expression analysis. 
differentiation; correlated with a favorable prognosis in AML and increased azacitidine-induced apoptosis (Figure 8B). Further, a response to azacitidine treatment correlated with a high ABR expression. Our data indicate the functional role of $\mathrm{ABR}$ as a new player in myelopoiesis and AML. Because ABR has been shown to control innate immune response and ABR deletion has been found in several human cancers, targeted treatment that increase endogenous levels of ABR might provide novel therapeutic strategies to enhance the treatment response for patients not only restricted to AML, as the immune system is able to recognize and attack cancer cells in general.

\section{MATERIALS AND METHODS}

\section{Human cell samples from AML patients and healthy donors}

AML patient samples belonging to the cohort that received non-myeloablative hematopoietic stem cell (NMA-HSC) transplantation [27] and bone marrow samples from patients without any hematopoietic disease were obtained from University Hospital of Leipzig. Samples from azacitidine-treated AML patients were obtained from University Hospital of Halle. Azacitidine was administered as previously described [28]. The study protocols used for AML patient sample collection were approved by the ethics committees of the participating centres. All patients provided written informed consent in accordance with the Declaration of Helsinki. All samples were analysed by cytogenetic and molecular genetic analysis.

\section{Animals}

$\mathrm{C} 57 \mathrm{Bl} / 6$ mice were bred at the Animal Facility at the University of Leipzig, housed, treated and handled in accordance with the guidelines of the University Leipzig Animal Care Committee and the Regional Board of Animal Care for Leipzig.

\section{Cell culture and flow cytometry analysis}

U937 cells were maintained in RPMI 1640 medium supplemented with $10 \%$ fetal bovine serum (FBS), 1\% penicillin-streptomycin. For myeloid differentiation of U937 cells, $1 \times 10^{6}$ cells were induced once with 10nM PMA (phorbol 12-myristate 13-acetate). For differentiation of ABR siRNA transfected U937 cells, 1nM PMA was used. Mouse bone marrow cells were obtained from tibiae and femora from $\mathrm{C} 57 \mathrm{Bl} / 6$ wild-type mice and were seeded at $1 \times 10^{6} / \mathrm{mL}$ in Dulbecco's modified
A

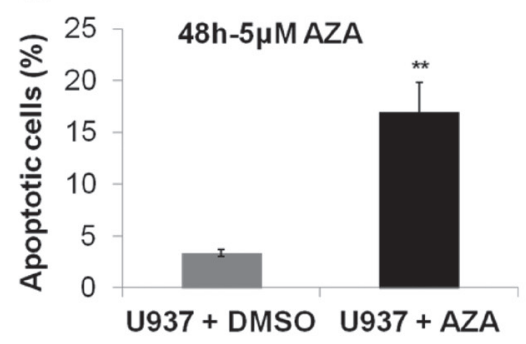

D

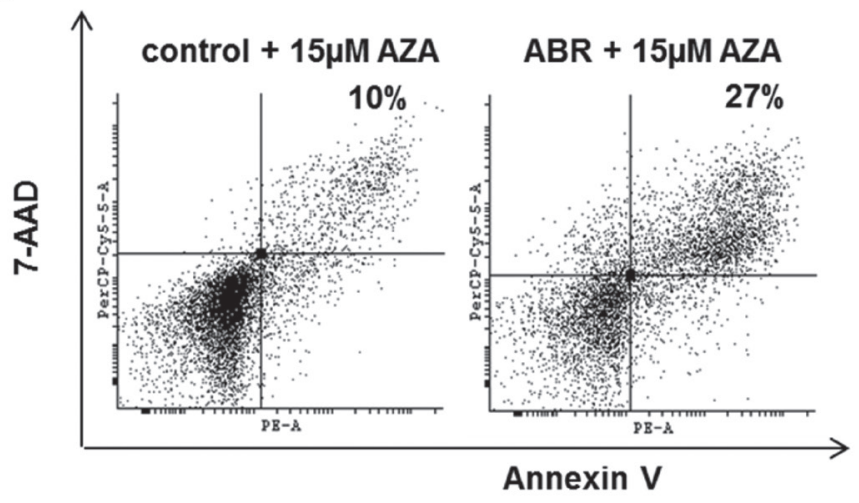

B

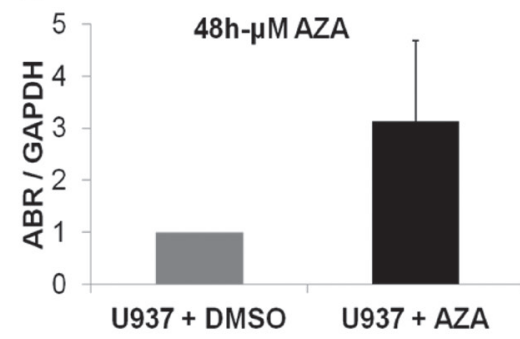

C

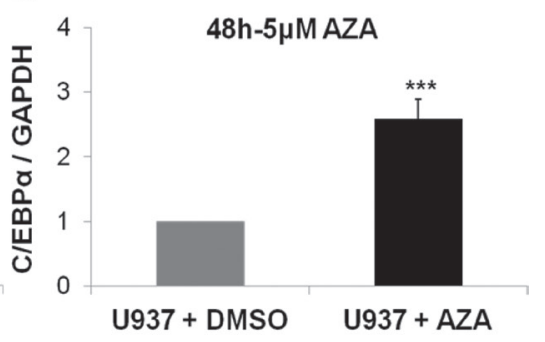

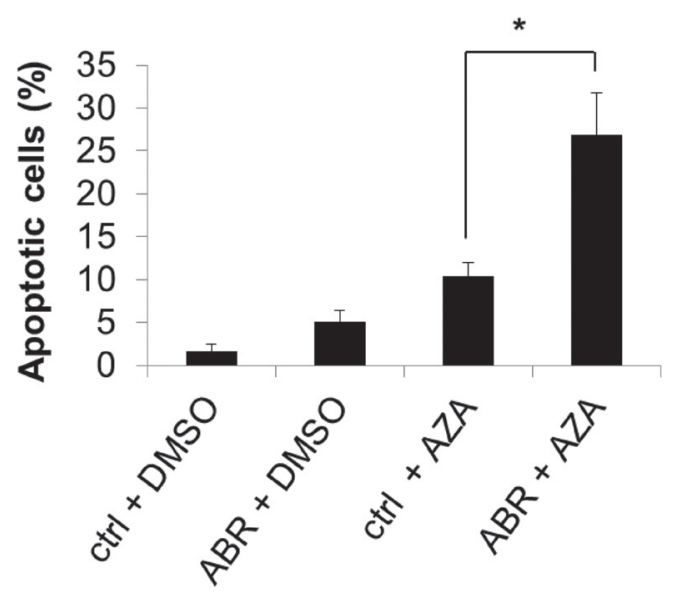

Figure 7: ABR overexpression enhances azacitidine-induced apoptosis. (A-B) Flow cytometry analysis for Annexin V and 7-AAD staining in non-transduced U937 cells (A-C) or in U937 cells stably expressing ABR or control sequence (D) or in to analyse apoptosis. Cells were treated with $5 \mu \mathrm{M}(\mathrm{A}-\mathrm{C})$ or $15 \mu \mathrm{M}$ (D) azacitidine (AZA) or DMSO for 48 hours. (C-D) qPCR analysis of $A B R$ (B) and $C E B P A(\mathrm{C})$ expression in non-transduced U937 cells after AZA treatment $(5 \mu \mathrm{M})$. Total data are represented as mean $\pm \mathrm{SD}$ from 3 representative experiments. ${ }^{* *} P \leq .01 ;{ }^{*} P \leq .05$. 
Eagle's medium (DMEM) complemented with 10\% FBS, $1 \%$ penicillin-streptomycin and dexamethasone $\left(10^{-8} \mathrm{M}\right)$. Differentiation of granulocytic and monocytic lineages were induced with G-CSF (1 ng/ml) or M-CSF $(20 \mathrm{ng} / \mathrm{ml})$, respectively. Treatment of the cells was done daily during the experimental process. Cell differentiation was assessed by flow cytometry analysis using PE-conjugated mouse anti-human CD11b antibody (BD Biosciences), FITCconjugated rat anti-mouse F4/80 and FITC-conjugated rat anti-mouse Gr-1 (eBioscience). Apoptosis was measured with an Annexin V Apoptosis Detection Kit I (BD Bioscience) according to the manufacturer's instructions. For Rac inhibition, NSC23766 (Selleckbiochem) was added daily to the cell culture medium.

\section{mRNA and miRNA detection by quantitative real-time PCR}

Total RNA was isolated from cells using TRIzol reagent (Invitrogen). RNA (100 ng) was used to synthesize cDNA by reverse transcription. Equal amounts of cDNA were taken for a subsequent quantitative real-time PCR (qPCR) using the SYBR Green PCR kit (Applied Biosystems) as previously described [29]. The relative quantity of mRNA was determined by the comparative threshold cycle method using glyceraldehyde-3phosphate dehydrogenase (GAPDH) or $18 \mathrm{~S}$ ribosomal RNA expression for normalization. All reactions were performed in triplicates. Primer sequences are provided in Supplementary Table 1. MiRNA quantification was performed as previously described [29] by using RNU6B expression for normalization. Corresponding reverse

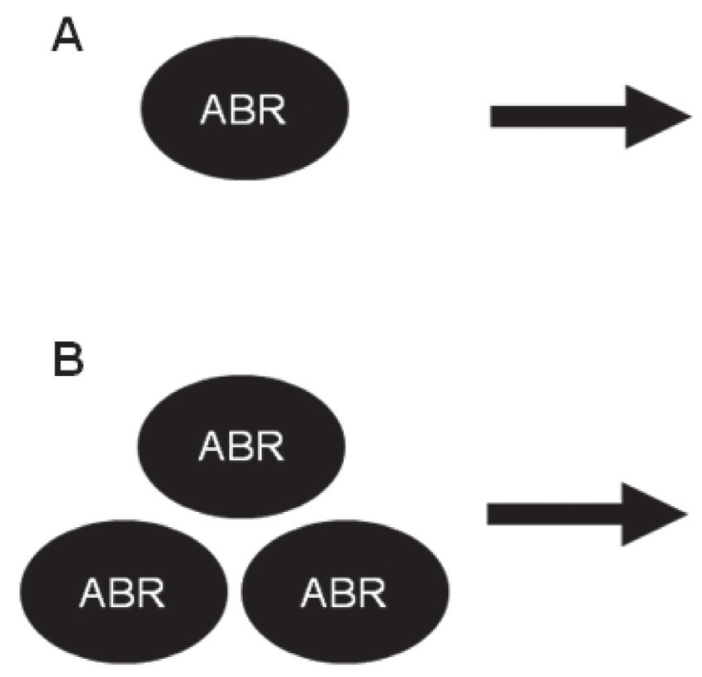

transcription (RT) and qPCR primers for RNU6B and miR-223 were obtained from Applied Biosystems. All reactions were performed in triplicates.

\section{Immunoblot analyses}

Immunoblot analyses were performed as previously described [29]. For ABR protein detection, a mouse monoclonal antibody anti-ABR (Abcam), and for $\mathrm{C} / \mathrm{EBP} \alpha$ protein detection, a rabbit monoclonal antibody anti-C/ $\mathrm{EBP} \alpha$ (Abcam) was used. Polyclonal rabbit anti-GAPDH (sc-25778; Santa Cruz Biotechnology) and b-tubulin (sc-9104) antibodies were used for normalization. The immunoreactivity was determined using an enhanced chemiluminescence method (Amersham Biosciences) according to the manufacturer's instructions. The band intensities were quantified using ImageJ software (National Institute of Health, Bethesda, MD).

\section{Transfections}

Transfection of pEYFP-ABR, pcDNA3.1-E2F1 and the according control vectors as well as ABR siRNA, CEBP $\alpha$ siRNA or control siRNA in U937 cells was performed via electroporation with a specific Nucleofactor Kit according to the manufacturer's instructions (Lonza). $2 \mu \mathrm{g}$ of DNA plasmid or $800 \mathrm{nM}$ siRNA were used for each transfection. The pEYFP-ABR construct, as well as the empty vector pEYFP, were kindly provided by Professor Dr. N. Heisterkamp [23]. The siRNA for ABR and $\mathrm{C} / \mathrm{EBP} \alpha$ were purchased from Invitrogen. The siRNA sequences are provided in Supplementary Table 2.

\section{Block of myeloid differentiation,}

AML

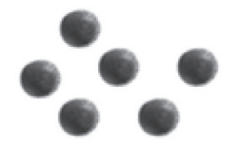

\section{Myeloid differentiation, Azacitidine-induced apoptosis, Favorable prognosis in AML}

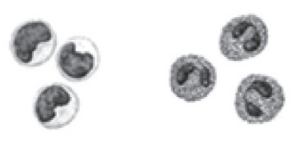

Figure 8: Schematic representation of a model for the role of ABR in normal myelopoiesis and in AML. A knockdown of ABR expression resulted in block of myeloid differentiation. In accordance to this, ABR expression is reduced in AML (A). Conversely, ABR overexpression enhanced myeloid differentiation and azacitidine-induced apoptosis. A high $A B R$ expression correlated with better outcome in AML (B). 


\section{Lentiviral transduction}

Lentiviral vector for EYFP-Abr in pCCL-cppt178MNDU3 was a gift from Professor Dr. N. Heisterkamp (Addgene plasmid \# 38155) [23]. 293TN cells were cotransfected using polyethylenimine (PEI) with either control vector or EYFP-ABR in pCCL-cppt178-MNDU3. Packaging plasmids psPAX2 (Addgene plasmid \# 12260) and pMD2.G (Addgene plasmid \# 12259) were gifts from Didier Trono. Virus-containing supernatants were collected at 24 and 48 hours after transfection and stored at $-80^{\circ} \mathrm{C}$. Lentiviral transduction of U937 cells was performed in 24well culture dishes for 2 consecutive days.

\section{Statistical analysis}

We used Student $t$ test to determine the statistical significance of experimental results. A $P$ value of .05 or less was considered significant. The results were represented as the mean \pm standard deviation (SD) from at least three independent experiments. The AML patients that received NMA-HSC transplantation were dichotomized into $A B R$ high and $A B R$ low expressers using a median cut. For time-to-event analyses, we calculated survival estimates using the Kaplan-Meier method, and compared groups by the log-rank test [30]. Azacitidinetreated AML patients were divided into responders and non-responders, according to blast clearance $(\leq 5 \%)$ in the bone marrow on day 15 after start of the first azacitidine treatment cycle [28]. Kruskal test was used for statistical evaluation of $A B R$ expression.

\section{ACKNOWLEDGMENTS}

This study was supported by grants from DFG (German Research Foundation, BE 2042/12-1, BE 2042/71 and GRK1591); Deutsche José Carreras LeukämieStiftung e.V. (DJCLS R 11/17, DJCLS 17R/2016, DJCLS R15/18, DJCLS R12/31 to G.B. and DJCLS F14/03 to C.Y.N.); Deutsche Krebshilfe, Zusammen gegen den Krebs e.V. and Wilhelm Sander Stiftung (No. 2013.153.1 and No. 2015.093.1) (to G.B.), and Coordination for the Improvement of Higher Education Personnel (BEX3056 / 07-4, CAPES, Brazil) to C.Y.N.

\section{CONFLICTS OF INTEREST}

None.

\section{REFERENCES}

1. Ferrara F, Schiffer CA. Acute myeloid leukaemia in adults. Lancet Oncol. 2013; 381:484-95.

2. Rosenbauer F, Tenen DG. Transcription factors in myeloid development: balancing differentiation with transformation. Nat Rev Immunol. 2007; 7:105-17.
3. Tenen DG, Hromas R, Licht JD. Transcription factors, normal myeloid development, and leukemia. Blood. 1997; 90:489-519.

4. Heisterkamp N, Morris C, Groffen J. ABR, an active BCRrelated gene. Nucleic Acids Res. 1989; 17:31-8821.

5. Arlinghaus RB. Bcr: a negative regulator of the Bcr-Abl oncoprotein in leukemia. Oncogene. 2002; 21:8560-7.

6. Wozniak K, Piaskowski S, Gresner SM, Golanska E, Bieniek E, Bigoszewska K, Sikorska B, Szybka M, Kulczycka-Wojdala D, Zakrzewska M, Zawlik I, Papierz $\mathrm{W}$, Stawski R, et al. BCR expression is decreased in meningiomas showing loss of heterozygosity of 22q within a new minimal deletion region. Cancer Genet Cytogenet. 2008; 183:14-20.

7. McDonald JD, Daneshvar L, Willert JR, Matsumura K, Waldman F, Cogen PH. Physical mapping of chromosome 17 p13.3 in the region of a putative tumor suppressor gene important in medulloblastoma. Genomics. 1994; 23:229-32.

8. Willert JR, Daneshvar L, Sheffield VC, Cogen PH. Deletion of chromosome arm 17p DNA sequences in pediatric high-grade and juvenile pilocytic astrocytomas. Genes Chromosom Cancer. 1995; 12:165-72.

9. Liscia DS, Morizio R, Venesio T, Palenzona C, Donadio M, Callahan R. Prognostic significance of loss of heterozygosity at loci on chromosome 17p13.3-ter in sporadic breast cancer is evidence for a putative tumour suppressor gene. Br J Cancer. 1999; 80:821-6.

10. Ohgushi M, Matsumura M, Eiraku M, Murakami K, Aramaki T, Nishiyama A, Muguruma K, Nakano T, Suga H, Ueno M, Ishizaki T, Suemori H, Narumiya S, et al. Molecular pathway and cell state responsible for dissociation-induced apoptosis in human pluripotent stem cells. Cell Stem Cell. 2010; 7:225-39.

11. Heisterkamp N, Kaartinen V, van Soest S, Bokoch GM, Groffen J. Human ABR encodes a protein with GAPrac activity and homology to the DBL nucleotide exchange factor domain. J Biol Chem. 1993; 268:16903-6.

12. Cunnick JM, Schmidhuber S, Chen G, Yu M, Yi SJ, Cho YJ, Kaartinen V, Minoo P, Warburton D, Groffen J, Heisterkamp $\mathrm{N}$. Bcr and Abr cooperate in negatively regulating acute inflammatory responses. Mol Cell Biol. 2009; 29:5742-50.

13. Mulloy JC, Cancelas JA, Filippi MD, Kalfa TA, Guo F, Zheng Y. Rho GTPases in hematopoiesis and hemopathies. Blood. 2010; 115:936-947.

14. Thomas EK, Cancelas JA, Chae HD, Cox AD, Keller PJ, Perrotti D, Neviani P, Druker BJ, Setchell KD, Zheng Y, Harris CE, Williams DA. Rac guanosine triphosphatases represent integrating molecular therapeutic targets for BCRABL-induced myeloproliferative disease. Cancer Cell. 2007; 12:467-478.

15. Thomas EK, Cancelas JA, Zheng Y, Williams DA. Rac GTPases as key regulators of p210-BCRABL-dependent leukemogenesis. Leukemia. 2008; 22:898-904. 
16. Rozenveld-Geugien M, Baas IO, van Gosliga D, Vellenga E, Schuringa JJ. Expansion of normal and leukemic human hematopoietic stem/progenitor cells requires rac-mediated interaction with stromal cells. Exp Hematol. 2007; 35:782-92.

17. Heasman SJ, Ridley AJ. Mammalian Rho GTPases: new insights into their functions from in vivo studies. Nat Rev Mol Cell Biol. 2008; 9:690-701.

18. Heath V, Suh HC, Holman M, Renn K, Gooya JM, Parkin S, Klarmann KD, Ortiz M, Johnson P, Keller J. C/EBP-alpha deficiency results in hyperproliferation of hematopoietic progenitor cells and disrupts macrophage development in vitro and in vivo. Blood. 2004; 104:1639-47.

19. Zhang P, Iwasaki-Arai J, Iwasaki H, Fenyus ML, Dayaram T, Owens BM, Shigematsu H, Levantini E, Huettner CS, Lekstrom-Himes JA, Akashi K, Tenen DG. Enhancement of hematopoietic stem cell repopulating capacity and selfrenewal in the absence of the transcription factor C/EBP alpha. Immun. 2004; 21:853-63.

20. Wang D, D'Costa J, Civin CI, Friedman AD. C/EBPalpha directs monocytic commitment of primary myeloid progenitors. Blood. 2006; 108:1223-9.

21. Zhang DE, Hetherington CJ, Meyers S, Rhoades KL, Larson CJ, Chen HM, Hiebert SW, Tenen DG. CCAAT enhancer-binding protein (C/EBP) and AML1 (CBF alpha2) synergistically activate the macrophage colony-stimulating factor receptor promoter. Mol Cell Biol. 1996; 16:1231-40.

22. Smith LT, Hohaus S, Gonzalez DA, Dziennis SE, Tenen DG. PU.1 (Spi-1) and C/EBP alpha regulate the granulocyte colony-stimulating factor receptor promoter in myeloid cells. Blood. 1996; 88:1234-47.

23. Cho YJ, Cunnick JM, Yi SJ, Kaartinen V, Groffen J, Heisterkamp N. Abr and Bcr, two homologous Rac GTPaseactivating proteins, control multiple cellular functions of murine macrophages. Mol Cell Biol. 2007; 27:899-911.

24. Zhang DE, Zhang P, Wang ND, Hetherington CJ, Darlington GJ, Tenen DG. Absence of granulocyte colony-stimulating factor signaling and neutrophil development in CCAAT enhancer binding protein alpha-deficient mice . Proc Natl Acad Sci U S A. 1997; 94:569-74.

25. Fazi F, Rosa A, Fatica A, Gelmetti V, De Marchis ML, Nervi C, Bozzoni I. A minicircuitry comprised of microRNA-223 and transcription factors NFI-A and C/EBPalpha regulates human granulopoiesis. Cell. 2005; 123:819-31.

26. Pulikkan JA, Dengler V, Peramangalam PS, Peer Zada AA, Müller-Tidow C, Bohlander SK, Tenen DG, Behre G. Cell-cycle regulator E2F1 and microRNA-223 comprise an autoregulatory negative feedback loop in acute myeloid leukemia. Blood. 2010; 115:1768-78.

27. Gyurkocza B, Storb R, Storer BE, Chauncey TR, Lange T, Shizuru JA, Langston AA, Pulsipher MA, Bredeson CN, Maziarz RT, Bruno B, Petersen FB, Maris MB, et al. Nonmyeloablative allogeneic hematopoietic cell transplantation in patients with acute myeloid leukemia. J Clin Oncol. 2010; 28:2859-67.
28. Müller-Tidow C, Tschanter P, Röllig C, Thiede C, Koschmieder A, Stelljes M, Koschmieder S, Dugas M, Gerss J, Butterfaß-Bahloul T, Wagner R, Eveslage M, Thiem $\mathrm{U}$, et al. Azacitidine in combination with intensive induction chemotherapy in older patients with acute myeloid leukemia: The AML-AZA trial of the study alliance leukemia. Leukemia. 2016; 30:555-61.

29. Katzerke C, Madan V, Gerloff D, Bräuer-Hartmann D, Hartmann JU, Wurm AA, Müller-Tidow C, Schnittger S, Tenen DG, Niederwieser D, Behre G. Transcription factor $\mathrm{C} / \mathrm{EBP} \alpha$-induced microRNA-30c inactivates Notch1 during granulopoiesis and is downregulated in acute myeloid leukemia. Blood. 2013; 122:2433-42.

30. Vittinghoff E, Glidden DV, Shiboski SC, McCulloch CE. Regression Methods in Biostatistics: Linear, Logistic, Survival and Repeated Measures Models. Springer New York, NY, USA. 2005.

31. Debernardi S, Lillington DM, Chaplin T, Tomlinson S, Amess J, Rohatiner A, Lister TA, Young BD. Genome-wide analysis of acute myeloid leukemia with normal karyotype reveals a unique pattern of homeobox gene expression distinct from those with translocation-mediated fusion events. Gene Chomosome Cancer. 2003; 37:149-58.

32. Hass R, Bartels H, Topley N, Hadam M, Köhler L, Goppelt-Strübe M, Resch K. TPA-induced differentiation and adhesion of U937 cells: changes in ultrastructure, cytoskeletal organization and expression of cell surface antigens. Eur J Cell Biol. 1989; 48:282-93.

33. Herman JG, Baylin SB. Gene silencing in cancer in association with promoter hypermethylation. N Engl J Med. 2003; 349:2042-54. https://doi.org/10.1056/NEJMra023075.

34. Krug U, Koschmieder A, Schwammbach D, Gerss J, Tidow N, Steffen B, Bug G, Brandts CH, Schaich M, Röllig C, Thiede C, Noppeney R, Stelljes M, et al. Feasibility of Azacitidine Added to Standard Chemotherapy in Older Patients with Acute Myeloid Leukemia - A Randomised SAL Pilot Study. PLoS One. e52695. 2012; 7. https://doi. org/10.1371/journal.pone.0052695.

35. Gong D, Fei F, Lim M, Yu M, Groffen J, Heisterkamp N. Abr, a negative regulator of Rac, attenuates cockroach allergen-induced asthma in a mouse model. J Immunol. 2013; 191:4514-20.

36. Yu M, Gong D, Lim M, Arutyunyan A, Groffen J, Heisterkamp N. Lack of Bcr and Abr Promotes HypoxiaInduced Pulmonary Hypertension in Mice. PLoS One. e49756 ed. 2012; 7. https://doi.org/10.1371/journal. pone. 0049756.

37. Chen S, Li H, Li S, Yu J, Wang M, Xing H, Tang K, Tian Z, Rao Q, Wang J. Rac1 GTPase promotes interaction of hematopoietic stem/progenitor cell with niche and participates in leukemia initiation and maintenance in mouse. Stem Cells. 2016; 34:1730-41.

38. Cancelas JA, Jansen M, Williams DA. The role of chemokine activation of Rac GTPases in hematopoietic 
stem cell marrow homing, retention, and peripheral mobilization. Exp Hematol. 2006; 34:976-85. https://doi. org/10.1016/j.exphem.2006.03.016.

39. Gu Y, Filippi MD, Cancelas JA, Siefring JE, Williams EP, Jasti AC, Harris CE, Lee AW, Prabhakar R, Atkinson SJ, Kwiatkowski DJ, Williams DA. Hematopoietic Cell Regulation by Rac1 and Rac2 Guanosine Triphosphatases. Science (80-). 2003; 302:445-9. https://doi.org/10.1126/ science. 1088485 .

40. Somervaille TC, Cleary ML. Identification and characterization of leukemia stem cells in murine MLL-AF9 acute myeloid leukemia. Cancer Cell. 2006; 10:257-268.

41. Li Z, Huang H, Li Y, Jiang X, Chen P, Arnovitz S, Jiang $\mathrm{X}$, Chen P, Arnovitz S, Radmacher MD, Maharry K, Elkahloun A, Yang X, et al. Up-regulation of a HOXAPBX3 homeobox-gene signature following down-regulation of miR-181 is associated with adverse prognosis in patients with cytogenetically abnormal AML. Blood. 2012; 119:2314-24.

42. Schwind S, Maharry K, Radmacher MD, Mrózek K, Holland KB, Margeson D, Whitman SP, Hickey C, Becker H, Metzeler KH, Paschka P, Baldus CD, Liu S, et al. Prognostic significance of expression of a single microRNA, miR-181a, in cytogenetically normal acute myeloid leukemia: a Cancer and Leukemia Group B study. J Clin Oncol. 2010; 28:5257-64.

43. Papaemmanuil E, Gerstung M, Bullinger L, Gaidzik VI, Paschka P, Roberts ND, Potter NE, Heuser M, Thol F, Bolli N, Gundem G, Van Loo P, Martincorena I, et al. Genomic Classification and Prognosis in Acute Myeloid Leukemia. N Engl J Med. 2016; 374:2209-21.

44. Versluis J, In 't Hout FE, Devillier R, van Putten WL, Manz MG, Vekemans MC, Legdeur MC, Passweg JR, Maertens J, Kuball J, Biemond BJ, Valk PJ, van der Reijden BA, et al. Comparative value of post-remission treatment in cytogenetically normal AML subclassified by NPM1 and FLT3-ITD allelic ratio. Leukemia. 2017; 26-33.

45. Ivey A, Hills RK, Simpson MA, Jovanovic JV, Gilkes A, Grech A, Patel Y, Bhudia N, Farah H, Mason J, Wall K, Akiki S, Griffiths M, et al. Assessment of Minimal Residual Disease in Standard-Risk AML. N Engl J Med. 2016; 374:422-33.

46. Mangolini M, de Boer J, Walf-Vorderwülbecke V, Pieters $\mathrm{R}$, den Boer ML, Williams O. STAT3 mediates oncogenic addiction to TEL-AML1 in $\mathrm{t}(12 ; 21)$ acute lymphoblastic leukemia. Blood. 2013; 122:542-9. https://doi.org/10.1182/ blood-2012-11-465252.

47. Benekli M, Baumann H, Wetzler M. Targeting signal transducer and activator of transcription signaling pathway in leukemias. J Clin Oncol. 2009; 27:4422-32. https://doi. org/10.1200/JCO.2008.21.3264.

48. Biethahn S, Alves F, Wilde S, Hiddemann W, Spiekermann $\mathrm{K}$. Expression of granulocyte colony-stimulating factorand granulocyte-macrophage colony-stimulating factorassociated signal transduction proteins of the JAK/STAT pathway in normal granulopoiesis and in blast cells of acute myelogenous leukemia. Exp Hematol. 1999; 27:885-94.

49. Spiekermann K, Biethahn S, Wilde S, Hiddemann W, Alves F. Constitutive activation of STAT transcription factors in acute myelogenous leukemia. Eur J Haematol. 2001; 67:63-71.

50. Antonson P, Pray MG, Jacobsson A, Xanthopoulos KG. Myc inhibits CCAAT/enhancer-binding protein alpha-gene expression in HIB-1B hibernoma cells through interactions with the core promoter region. Eur J Biochem. 1995; 232:397-403.

51. Li LH, Nerlov C, Prendergast G, MacGregor D, Ziff EB. c-Myc represses transcription in vivo by a novel mechanism dependent on the initiator element and Myc box II. EMBO J. 1994; 13:4070-9.

52. Mink S, Mutschler B, Weiskirchen R, Bister K, Klempnauer $\mathrm{KH}$. A novel function for Myc: inhibition of C/EBPdependent gene activation. Proc Natl Acad Sci U S A. 1996; 93:6635-40.

53. Hofbauer SW, Krenn PW, Ganghammer S, Asslaber D, Pichler U, Oberascher K, Henschler R, Wallner M, Kerschbaum H, Greil R, Hartmann TN. Tiam1/Rac1 signals contribute to the proliferation and chemoresistance, but not motility, of chronic lymphocytic leukemia cells. Blood. 2014; 123:2181-8. https://doi.org/10.1182/ blood-2013-08-523563.

54. Schoofs T, Müller-Tidow C. DNA methylation as a pathogenic event and as a therapeutic target in AML. Cancer Treat Rev. 2011; 37:S13-S18.

55. Fenaux P, Mufti GJ, Hellström-Lindberg E, Santini V, Finelli C, Giagounidis A, Schoch R, Gattermann N, Sanz G, List A, Gore SD, Seymour JF, Bennett JM, et al. Efficacy of azacitidine compared with that of conventional care regimens in the treatment of higher-risk myelodysplastic syndromes: a randomised, open-label, phase III study. Lancet Oncol. 2009; 10:223-232.

56. Wang JY, Yu P, Chen S, Xing H, Chen Y, Wang M, Tang K, Tian Z, Rao Q, Wang J. Activation of Rac1 GTPase promotes leukemia cell chemotherapy resistance, quiescence and niche interaction. Mol Oncol. 2013; 5:907-16.

57. Schuster MB, Porse BT. C/EBPalpha: a tumour suppressor in multiple tissues? Biochim Biophys Acta. 2006; 1766:88-103. 